\title{
STUDI KOMPARATIF STIGMA TERHADAP ODHA PADA MAHASISWA TINGKAT I DAN TINGKAT III AKADEMI KEPERAWATAN PANTI KOSALA SURAKARTA
}

\author{
Wiwin Winarni ${ }^{1}$, Sesilia Natasya Aulia ${ }^{2}$
}

\begin{abstract}
Background : Giving stigma toward people who live with HIV/AIDS is not only can be found on common people who live in society but also among health workers. It is unbelievable if health workers whose education background is health will do the same thing toward people living with HIV/AIDS. Thus, it is necessary to have some strategies to prepare nursing students in order to reduce the discrimination which happen in health services facilities by health workers. Hence, the prevention efforts of HIV/AIDS cases in Indonesia can optimally be implemented.

The purpose of this study : was to analyze the diversity of stigma level toward people living with HIV/AIDS between the first year students and the third year students in Panti Kosala Nursing Academy.

This research used analytic with comparative design. The total population involved in this research were 150 students of Panti Kosala Nursing Academy which was then divided into two groups. Group number one was consisted of 75 students from grade one and group number two was consisted of 75 students from grade three. Random sampling was used as a sampling technic. Data was collected by using questionnaire. The data was then analyzed using Mann-Whitney aided by SPSS serial 16 .

There were three main results of this study : 1) The majority of first year students have high level of stigma toward people living with HIV/AIDS accounted for $57,33 \%$. 2)The majority of third year students have high level of stigma toward people living wth HIV/AIDS accounted for $53,33 \%$. 3)The analysis of Mann-Whitney shows significancy number $p>0,721$. It can be concluded that the stigma toward people living with HIV/AIDS of first year students as same as with the one of third year students.
\end{abstract}

Keywords: stigma, people living with HIV/AIDS, nursing students

\section{PENDAHULUAN}

Stigmatisasi terhadap ODHA (Orang dengan HIV/AIDS) tidak hanya terjadi di kalangan masyarakat umum namun hal ini juga ditemukan di kalangan tenaga kesehatan. Sangat disayangkan jika tenaga kesehatan dengan latar belakang pendidikan kesehatan juga melakukan diskriminasi terhadap ODHA. Oleh karena itu,diperlukan suatu upaya untuk mempersiapkan calon tenaga kesehatan sehingga tenaga kesehatan akan mampu merawat ODHA tanpa melakukan stigmatisasi dan diskriminasi di fasilitas pelayanan kesehatan. Dengan demikian, upaya pencegahan dan penanggulangan kasus HIV/AIDS di Indonesia dapat dilaksanakan dengan optimal.

Pada tahun 2015 diperkirakan terdapat 36.7 juta (34 juta-39.8 juta) orang hidup dengan HIV, meningkat sebanyak 3.4 juta dibandingkan tahun 2010. Sebanyak 2.1 juta diantaranya merupakan kasus baru HIV. Namun, dalam laporan yang sama terjadi penurunan kematian, WHO (World Health Organization) mencatat sejak AIDS ditemukan hingga akhir 2015 terdapat 34 juta orang meninggal dan di tahun 2015 tercatat sebesar 1.1 juta orang meninggal terkait dengan AIDS, menurun dibandingkan tahun 2010 sebesar 1.5 juta kematian. Di Indonesia, HIV/AIDS pertama kali 
ditemukan di Provinsi Bali pada tahun 1987. Hingga saat ini HIV/AIDS sudah menyebar di 407 kota dari 507 kabupaten/kota (80\%) di seluruh provinsi Indonesia (Kemenkes Rl, 2016).

Di Jawa Tengah sendiri pada tahun 2016 terdapat 747 kasus baru pada HIV dan 673 kasus baru pada AIDS, serta 78 orang meninggal akibat HIV/AIDS (Dinas Kesehatan Provinsi Jawa Tengah, 2016). Pada bulan Maret penanggulangan AIDS (KPA) Kota Solo mencatat jumlah pengidap HIV/AIDS yang terdeteksi di Solo dan sekitarnya awal tahun ini bertambah 112 orang. Perinciannya, 34 orang terdeteksi menderita HIV sedangkan 78 orang menderita AIDS. Tiga orang sudah meninggal dunia, salah satunya anak-anak serta ibunya juga yang terkena AIDS (Wakhidah, 2017).

Menurut Kamus Besar Bahasa Indonesia (KBBI) stigma adalah ciri negatif yang menempel pada pribadi seseorang karena pengaruh lingkungannya. Menurut Suranto, Siswaya dan Riswanti (2007) stigmatisasi dan diskriminasi berlebihan seringkali terjadi di masyarakat, sehingga menjadi penghalang utama bagi upaya pencegahan infeksi HIV. Adanya stigma atau "cap buruk" menyebabkan penderita atau keluarganya menjadi enggan memeriksakan diri untuk memastikan atau mencegah untuk tidak menularkannya pada orang lain. ODHA (Orang Dengan HIV/AIDS) sering mendapatkan "cap buruk" tentang penyakitnya. Diantaranya ODHA disebut-sebut menderita "penyakit penyimpangan seksual atau gay", "penyakit pergaulan bebas", "penyakit kaum nakal", "penyakit orang kulit hitam", atau "penyakit orang asing". Akibat cap buruk tersebut penderita dikucilkan, dan bahkan hak asasi mereka ditindas dengan mendiskriminasikan penderita.
Status HIV positif yang disandang menyebabkan ODHA menjadi sangat sensitif dengan lingkungan di sekitarnya. Maharani (2014) dalam wawancara yang dilakukan terhadap ODHA mendapatkan beberapa isu stigmatisasi dalam pelayanan kesehatan yang didengar ODHA sehingga membuat ODHA takut untuk melakukan pengobatan. Isuisu tersebut antara lain isu bahwa jenazah ODHA dibungkus plastik dan dimasukkan dalam peti, penggunaan Alat Pelindung Diri (APD) yang berlebihan, anggapan bahwa ODHA adalah orang yang tidak benar, wanita yang positif HIV tidak boleh punya anak dan penolakan terhadap akses pelayanan kesehatan.

Sangat disayangkan ternyata stigma dan diskriminasi yang dilakukan oleh tenaga kesehatan memang dialami oleh ODHA di fasilitas kesehatan. Beberapa sikap diskriminasi dan stigmatisasi yang dilakukan oleh tenaga kesehatan dapat dijelaskan oleh Maharani (2014) dalam penelitian dengan judul Stigma dan Diskriminasi ODHA Pada Pelayanan Kesehatan di Pekanbaru dengan menggunakan metode kualitiatif model fenomenologi. Hasil penelitian menyebutkan beberapa sikap diskriminasi yang diterima oleh ODHA dan keluarga atau temannya antara lain dilecehkan secara lisan dengan menyebut penyakit HIV dengan nada lantang, pemberian kode pada status pasien, penggunaan alat pelindung yang berlebihan, diisolasi dan mendapatkan tindakan medis tanpa informed consent.

Penelitian yang dilakukan oleh Pratikno (2008), dengan judul Stigma dan Diskriminasi oleh Petugas Kesehatan terhadap ODHA di Kabupaten Bengkalis Riau dipengaruhi oleh beberapa hal salah satunya adalah jenis tenaga kesehatan. Hasil penelitian 
menunjukkan bahwa tenaga medis /dokter memiliki stigma dan diskriminasi terhadap ODHA yang lebih rendah dibandingkan tenaga paramedis/perawat karena dokter memiliki persepsi yang lebih tinggi.

Padahal seharusnya dalam memberikan asuhan keperawatan kepada pasien, perawat harus tulus dan ikhlas tanpa mengharapkan imbalan. Ketulusan ini diwujudkan dengan sikap perawat yang tidak membeda-bedakan dalam melayani klien. Semua klien harus dilayani perawat dengan baik (Asmadi, 2008). Hasil penelitian yang dilakukan oleh Waluyo, Nova, dan Edison (2011) mengenai hubungan perilaku perawat terhadap orang dengan HIV/AIDS menunjukkan bahwa terdapat beberapa faktor yang mempengaruhi sikap perawat terhadap ODHA yaitu terkait faktor usia, jenis kelamin, tempat kerja, penghasilan, pengalaman kerja, latar belakang pendidikan, pelatihan HIV/AIDS, dan persepsi kemampuan merawat ODHA.

Adanya stigma dan diskriminasi oleh petugas kesehatan terhadap ODHA akan menghambat upaya pencegahan dan penanggulangan HIV/AIDS. Oleh karena itu, sangat diperlukan upaya dini untuk menghilangkan stigma dan diskriminasi terhadap ODHA di kalangan tenaga kesehatan. Mempersiapkan tenaga kesehatan yang memahami HIV/AIDS dan perawatannya merupakan hal yang dapat diupayakan untuk mencapai tujuan tersebut. Tujuan ini dapat dicapai dengan memfasilitasi interaksi mahasiswa dengan ODHA secara langsung melalui praktik klinik keperawatan. Nursalam (2011) menjelaskan pengalaman belajar klinik dan belajar lapangan merupakan proses transformasi mahasiswa untuk menjadi seorang perawat profesional. Proses ini memberikan kesempatan mahasiswa beradaptasi dalam melaksanakan praktik keperawatan profesional di tatanan nyata pelayanan kesehatan klinik/komunitas.

Berdasarkan hasil wawancara dengan beberapa mahasiswa keperawatan tingkat I Akademi Keperawatan Panti Kosala tentang HIV/AIDS didapatkan hasil 3 dari 10 mahasiswa masih belum mengerti benar tentang HIV/AIDS. Mahasiswa hanya mengetahui HIV/AIDS adalah penyakit yang menyerang kekebalan tubuh manusia dan menganggap bahwa jika mereka bertemu dengan ODHA mereka harus memakai masker dan menjaga jarak agar tidak tertular penyakit HIV/AIDS. Sedangkan wawancara yang dilakukan kepada beberapa mahasiswa tingkat akhir menunjukkan bahwa ketakutan mereka merawat ODHA semakin berkurang setelah mereka berinteraksi langsung dengan ODHA di rumah sakit.

Berdasarkan uraian latar belakang di atas dan belum adanya penelitian terkait stigmatisasi ODHA pada mahasiswa keperawatan, peneliti tertarik untuk melakukan penelitian tentang "Studi Komparatif ODHA (Orang dengan HIV/AIDS) Pada Mahasiswa Tingkat I dan Tingkat III".

\section{TUJUAN PENELITIAN}

Tujuan Umum penelitian ini adalah untuk mengetahui perbedaan stigma terhadap ODHA pada mahasiswa keperawatan. Sedangkan tujuan khususnya adalah untuk mengetahui gambaran stigma terhadap ODHA pada mahasiswa tingkat I dan mengetahui gambaran stigma terhadap ODHA pada mahasiswa tingkat III Akademi Keperawatan Panti Kosala Surakarta.

\section{DESAIN PENELITIAN}

Penelitian ini merupakan bentuk penelitian analitik dengan desain 
komparatif untuk mengetahui perbedaan stigmatisasi terhadap ODHA pada mahasiswa tingkat I dan tingkat III. Pengumpulan data dilakukan dengan menggunakan kuesioner. Analisa data pada penelitian ini menggunakan uji Mann Whitney dengan bantuan SPSS 16.

\section{POPULASI, SAMPEL, DAN TEKNIK SAMPLING}

Populasi pada penelitian ini adalah mahasiswa tingkat I dan tingkat III Akademi Keperawatan Panti Kosala Surakarta yang berjumlah 275 orang. Berdasarkan tabel Krecjie, jumlah sampel yang digunakan pada penelitian ini berjumlah 150 mahasiswa yang dibagi menjadi dua kelompok yaitu 75 mahasiswa tingkat I dan 75 mahasiswa tingkat III. Teknik sampling yang peneliti gunakan adalah simple random sampling.

\section{HASIL PENELITIAN}

Berdasarkan penelitian yang telah dilakukan bulan Maret 2018 hasil penelitian mengenai studi komparatif stgmatisasi terhadap ODHA pada mahasiswa tingkat I dan III adalah sebagai berikut :

Tabel 1.

Distribusi Frekuensi Stigmatisasi terhadap ODHA pada Mahasiswa Tingkat I dan Tingkat III

\begin{tabular}{cccc}
\hline & Stigma & $\mathrm{f}$ & $\%$ \\
\hline \multirow{2}{*}{ Tingkat I } & Rendah & 32 & 42.67 \\
& Tinggi & 43 & 57.33 \\
\multirow{2}{*}{ Tingkat III } & Dasar & 35 & 46.67 \\
& Lanjut & 40 & 53.33 \\
\hline
\end{tabular}

Berdasarkan tabel 1 didapatkan informasi bahwa sebagian besar mahasiswa tingkat I mempunyai tingkat stigma yang tinggi terhadap ODHA 43 mahasiswa (57.33\%) dan sebanyak 32 mahasiswa (42.67\%) mahasiswa mempunyai stigma yang rendah terhadap ODHA. Sebagian besar mahasiswa tingkat III mempunyai stigma tinggi terhadap ODHA sebanyak 40 mahasiswa $(53.33 \%)$ dan mahasiswa dengan stigma rendah terhadap ODHA sejumlah 35 mahasiswa $(46,67 \%)$.

Tabel 2.

Pengalaman Merawat ODHA

\begin{tabular}{cccc}
\hline & $\begin{array}{c}\text { Merawat } \\
\text { ODHA }\end{array}$ & $f$ & $\%$ \\
\hline \multirow{2}{*}{ Tingkat I } & Pernah & 0 & 0 \\
& Tidak & 75 & 100 \\
Tingkat III & Pernah & 50 & 66.67 \\
& Tidak & 25 & 33.33 \\
\hline
\end{tabular}

Tabel 2 menunjukkan bahwa seluruh mahasiswa tingkat I belum mempunyai pengalaman merawat ODHA (100\%) sedangkan sebagian besar mahasiswa tingkat III sudah mempunyai pengalaman merawat ODHA sebanyak 50 mahasiswa $(66.67 \%)$ dan 25 mahasiswa $(33.33 \%)$ yang belum memiliki pengalaman merawat ODHA saat praktik di rumah sakit.

Tabel 3.

Hasil Analisa Mann Whitney

\begin{tabular}{ccc}
\hline & $\mathrm{n}$ & $p$ \\
\hline Stigma & 75 & 0.721 \\
Tingkat I & & \\
Stigma & 75 & \\
Tingkat III & & \\
\hline
\end{tabular}

Berdasarakan analisa uji MannWhitney pada tabel 3 diperoleh angka significancy 0.721 . Karena nilai p >0.05, dapat disimpulkan bahwa tidak ada perbedaan bermakna antara stigma mahasiswa tingkat I dan stigma mahasiswa tingkat III terhadap ODHA.

\section{PEMBAHASAN}

Berdasarkan tabel 1 didapatkan bahwa sebagian besar mahasiswa 
tingkat I mempunyai tingkat stigma yang tinggi terhadap ODHA sejumlah $57.33 \%$ dan sebanyak $42.67 \%$ mahasiswa mempunyai stigma yang rendah terhadap ODHA. Menurut Ardhiyanti, Lusiana, dan Megasari (2015), stigma adalah bentuk prasangka (prejudice) yang mendiskreditkan atau menolak seseorang atau kelompok karena mereka dianggap berbeda dengan diri kita atau kebanyakan orang. Stigma berhubungan dengan kekuasaan dan dominasi di masyarakat. Pada puncaknya, stigma akan menciptakan ketidaksetaraan sosial. Stigma berurat akar di dalam struktur masyarakat, dan juga dalam normanorma dan nilai-nilai yang mengatur kehidupan sehari-hari, ini menyebabkan beberapa kelompok menjadi kurang dihargai dan merasa malu, sedangkan kelompok lainnya merasa superior.

Rohan, et al., (2017) menjelaskan bahwa diskriminasi terhadap ODHA dapat terjadi karena kurangnya informasi yang benar mengenai HIV/AIDS khususnya mengenai bagaimana cara penularan HIV/AIDS. Hal ini mencakup hal-hal apa saja yang dapat menularkan dan apa yang tidak dapat menularkan. Shaluhiyah, Musthofa dan Widjanarko (2015) menyebutkan kesalahpahaman atau kurangnya pengetahuan masyarakat tentang HIV/AIDS seringkali berdampak pada ketakutan masyarakat terhadap ODHA sehingga memunculkan penolakan terhadap ODHA. Kurang pengetahuan mengenai HIV/AIDS pada mahasiswa tingkat I dapat dimungkinkan karena mata kuliah yang didapatkan oleh mahasiswa pada tahun pertama belum mencakup mengenai konsep HIV/AIDS. Selain itu, mahasiswa juga belum mendapatkan pengalaman praktik di rumah sakit. Hasil ini dibuktikan dengan tabel 2 yang menunjukkan bahwa seluruh mahasiswa tingkat I belum pernah memiliki pengalaman merawat ODHA. Kedua hal inilah yang dapat menyebabkan mahasiswa tingkat I mempunyai stigma yang tinggi terhadap ODHA. Penelitian yang dilakukan oleh Febrianti (2017) mengenai faktor-faktor yang berhubungan dengan stigma terhadap ODHA menunjukkan bahwa tingkat pengetahuan dan interaksi dengan ODHA di kalangan remaja SMA mempengaruhi stigmatisasi terhadap ODHA. Tingkat pengetahuan yang kurang dan interaksi dengan ODHA yang minim akan menyebabkan stigma yang tinggi terhadap ODHA.

Berdasarkan tabel 1 didapatkan bahwa sebagian besar mahasiswa tingkat III mempunyai stigma tinggi terhadap ODHA sebanyak 40 mahasiswa (53.33\%) dan mahasiswa dengan stigma rendah terhadap ODHA sejumlah 35 mahasiswa (46.67\%). Gambaran stigma yang didapatkan pada mahasiswa tingkat III tidak sesuai dengan uraian teori yang disampaikan oleh Febrianti (2017), yang menyatakan bahwa tingkat pengetahuan yang tinggi mengenai HIV/AIDS akan menurunkan stigmatisasi terhadap ODHA. Individu dengan tingkat pengetahuan yang tinggi mengenai HIV/AIDS tentunya akan cenderung mempunyai stigma yang rendah terhadap ODHA demikian juga sebaliknya.

Stigma yang tinggi terhadap ODHA di kalangan mahasiswa tingkat III dapat dimungkinkan karena adanya faktor lain yang ikut berkontribusi dalam pembentukan stigma yaitu tingkat interaksi dengan ODHA. Tingkat interaksi atau pengalaman merawat ODHA selama periode praktik di rumah sakit tentunya akan mempengaruhi pembentukan stigma khususnya di kalangan tenaga kesehatan. Hal ini sesuai dengan 
informasi yang disajikan pada tabel 2. Berdasarkan tabel 2 didapatkan informasi bahwa sebagian besar mahasiswa tingkat III sudah mempunyai pengalaman merawat ODHA sebanyak 50 mahasiswa $(66.67 \%)$ dan 25 mahasiswa $(33.33 \%)$ yang belum memiliki pengalaman merawat ODHA saat praktik di rumah sakit. Salah satu tujuan yang diharapkan dari pengalaman belajar klinik dan lapangan sebagaimana disampaikan oleh Nursalam (2011), yaitu siswa dapat menampilkan sikap/tingkah laku profesional saat melakukan praktik sesuai dengan kompetensi bidang mereka.

Berdasarkan analisa uji MannWhitney pada tabel 3 diperoleh angka significancy 0.721 . Karena nilai $p>0.05$, dapat disimpulkan bahwa tidak ada perbedaan bermakna antara stigma mahasiswa tingkat I dan stigma mahasiswa tingkat III terhadap ODHA. Secara teori seharusnya ada perbedaan stigma yang ditunjukkan oleh mahasiswa tingkat III jika dibandingkan dengan mahasiswa tingkat I. Secara akademis, mahasiswa keperawatan tingkat III sudah mendapatkan perkuliahan teori mengenai HIV/AIDS dan sudah mempunyai pengalaman berinteraksi secara langsung dengan ODHA di lahan praktik. Namun hasil penelitian ini menunjukkan hasil yang berbeda. Penelitian yang dilakukan oleh Shaluhiyah, Musthofa dan Widjanarko (2015) mengenai stigma masyarakat terhadap ODHA menunjukkan bahwa tidak hanya faktor tingkat pengetahuan mengenai HIV/AIDS dan tingkat interaksi dengan ODHA yang dapat mempengaruhi pembentukan stigma. Faktor-faktor lain yang dapat berpengaruh antara lain adalah persepsi tentang ODHA, faktor sikap tetangga, keluarga dan tokoh masyarakat terhadap ODHA juga ikut berkontribusi dalam stigmatisasi ODHA. Adanya perilaku keluarga yang memberikan stigma ODHA dapat memperkuat diskriminasi dan penolakan dari masyarakat. Selain keluarga, tokoh masyarakat merupakan salah satu faktor lingkungan sosial yang memiliki peranan penting terjadinya stigma terhadap ODHA. Apabila seorang tokoh masyarakat memberikan stigma terhadap ODHA, masyarakat di sekitarnya memiliki kemungkinan juga akan terpengaruh untuk melakukan hal yang sama. Tindakan dan sikap tokoh masyarakat dapat dijadikan referensi oleh masyarakat dalam mengubah perilaku sehat termasuk yang terkait dengan penularan HIV dan menurunkan stigma terhadap ODHA.

Jika dikaitkan dengan penelitian ini maka tingginya stigma mahasiswa tingkat III dapat dimungkinkan karena faktor lingkungan dimana mahasiswa tersebut berada. Sangat dimungkinkan jika tenaga kesehatan lain yang berinteraksi dengan mahasiswa ikut mempengaruhi pembentukan stigma pada mahasiswa tersebut. Sebagaimana penelitian yang dilakukan oleh Waluyo, Nova, dan Edison (2011) mengenai hubungan perilaku perawat terhadap orang dengan HIV/AIDS yang menunjukkan bahwa terdapat beberapa faktor yang mempengaruhi sikap perawat terhadap ODHA yaitu terkait faktor usia, jenis kelamin, tempat kerja, penghasilan, pengalaman kerja, latar belakang pendidikan, pelatihan HIV/AIDS, dan persepsi kemampuan merawat ODHA.

\section{KESIMPULAN}

1. Mayoritas mahasiswa tingkat I mempunyai stigma yang tinggi terhadap ODHA sebanyak $57.33 \%$.

2. Mayoritas mahasiswa tingkat III memiliki stigma yang tinggi 
terhadap ODHA sebanyak $53.33 \%$.

3. Berdasarakan analisa uji MannWhitney pada tabel 4.4 diperoleh angka significancy 0.721 . Karena nilai $p>0.05$, dapat disimpulkan bahwa tidak ada perbedaan bermakna antara stigma mahasiswa tingkat I dan stigma mahasiswa tingkat III terhadap ODHA.

\section{SARAN}

1. Bagi institusi pendidikan keperawatan disarankan untuk dapat memberikan kesempatan praktik klinik bagi mahasiswa yang berkaitan langsung dengan perawatan ODHA secara intensif sehingga akan meningkatkan intensitas interaksi langsung antara mahasiswa dengan ODHA.

2. Bagi peneliti selanjutnya disarankan untuk melakukan penelitian mengenai analisa faktor-faktor yang mempengaruhi keberhasilan praktik klinik keperawatan dalam membantu menurunkan stigma di kalangan tenaga kesehatan.

\section{DAFTAR PUSTAKA}

Ardhiyanti, Y., N. Lusiana dan K. Megasari. 2015. Bahan Ajar AIDS pada Asuhan Kebidanan. https://books.google.co.id/books ?id=ej. Diakses pada tanggal 28 Oktober 2017.

Asmadi. 2008. Teknik Prosedural Perawatan Konsep dan Aplikasi Kebutuhan Dasar Klien. https://books.google.co.id/books ?id=IJ3P1. Diakses pada tanggal 7 Oktober 2017.

Dinas Kesehatan Provinsi Jawa Tengah. 2016. Buku Saku Kesehatan Triwulan 2 Tahun 2016.http://www.dinkesjatengpr ov.go.id/v2015/dokumen/bukus aku tw2 2016/mobile/index.htm $\# \mathrm{p}=1$. Diakses pada tanggal 13 Oktober 2017.

Febrianti. 2017. Faktor-Faktor Yang Berhubungan Dengan Stigma Terhadap Orang Dengan HIV/AIDS (ODHA). Jurnal Endurance. Volume 2. No 2. Pekanbaru. Diakses tanggal 15 Maret 2018.

Kamus Besar Bahasa Indonesia. https://kbbi.kemdikbud.go.id/ent ri/Stigma. Diakses pada tanggal 7 Oktober 2017.

Kementrian Kesehatan Republik Indonesia. 2016. Situasi Penyakit HIVIAIDS di Indonesia.http://www.pusdatin.k emkes.go.id/article/view/. Diakses pada tanggal 5 Oktober 2017.

Maharani, R. 2014. "Stigma dan Diskriminasi Orang Dengan HIV/AIDS (ODHA) Pada Pelayanan Kesehatan di Kota Pekanbaru". Jurnal Kesehatan Komunitas. Volume 2, No 5. Pekanbaru. Diunduh pada tanggal 14 Maret 2018.

Nursalam. 2011. Manajamen Keperawatan : Aplikasi dalam Praktik Keperawatan Profesional. Salemba Medika, Jakarta.

Pratikno, H. 2008. Stigma dan Diskriminasi oleh Petugas Kesehatan Terhadap ODHA di Kabupaten Bengkalis Propinsi Riau. Tesis. Universitas Gadjah Mada.Yogyakarta.

Rohan, H. H., et al. 2017. Buku Kesehatan Reproduksi Pengenalan Penyakit Menular Reproduksi dan Pencegahan. Intimedia, Malang. 
Shaluhiyah, Z., S. B. Musthofa dan B. Widjanarko. 2015. "Stigma Masyarakat Terhadap Orang Dengan HIV/AIDS. Jurnal Kesehatan Masyarakat Nasional. Voume 9. No 4. Universitas Diponegoro.

Suranto, Z.H.A., K. Siswaya dan Riswanti. 2007. Bahaya Narkoba, Seks Bebas, dan HIV/AIDS. Mediatama, Surakarta.

Wakhidah, H. A. 2017. Pengidap HIV/AIDS di Solo Tahun Ini Bertambah 112 orang. http://m.solopos.com/. Diakses pada tanggal 6 Oktober 2017.
Waluyo, A., P.A. Nova dan C. Edison. 2011. "Perilaku Perawat terhadap Orang dengan HIV/AIDS di Rumah Sakit dan Puskemas". Jurnal Keperawatan Indonesia. Volume 14, No. 2. Depok. Diunduh pada tanggal 7 Oktober 2017.

${ }^{1}$ Dosen Akper Panti Kosala Surakarta

${ }^{2}$ Mahasiswa Akper Panti Kosala Surakarta 